\title{
Trophic niches of benthic crustaceans in the Pechora Sea suggest that the invasive snow crab Chionoecetes opilio could be an important competitor
}

\author{
Anna Gebruk ${ }^{1,2} \cdot$ Anna K. Zalota $^{3} \cdot$ Polina Dgebuadze $^{4}$ - Yulia Ermilova ${ }^{2} \cdot$ Vassily A. Spiridonov $^{3} \cdot$ Nikolay Shabalin $^{2}$. \\ Lea-Anne Henry ${ }^{1} \cdot$ Sian F. Henley ${ }^{1} \cdot$ Vadim O. Mokievsky ${ }^{3}$
}

Received: 28 February 2020 / Revised: 12 October 2020 / Accepted: 21 November 2020 / Published online: 8 December 2020

(c) The Author(s) 2020

\begin{abstract}
Expanding human activities alongside climate change, the introduction of invasive species and water contamination pose multiple threats to the unique marine ecosystems of the Pechora Sea in the Russian Arctic. Baseline data on biodiversity and responses to environmental change are urgently needed. Benthic decapod crustaceans are globally distributed and play an important role in fisheries, yet their roles in food webs are less understood. In this study, we used an integrated approach combining stomach content analysis and stable isotope analyses $\left(\delta^{13} \mathrm{C}\right.$ and $\left.\delta^{15} \mathrm{~N}\right)$ to examine the trophic niches of three decapod species in the Pechora Sea including the invasive snow crab Chionoecetes opilio and two species of native decapods, the spider crab Hyas araneus and the hermit crab Pagurus pubescens. Stomach contents of 75 decapods were analysed $(C$. opilio $n=23 ; H$. araneus $n=9 ;$. pubescens $n=43$ ), and 20 categories of prey items were identified with the most frequently occurring prey items being bivalve molluscs (Ciliatocardium ciliatum, Ennucula tenuis, Macoma calcarea), polychaetes, crustaceans and plant debris. Bayesian ellipse analyses of stable isotope signatures $(n=40)$ revealed that $C$. opilio displays an overlapping trophic niche with the two native decapods, providing direct evidence that the invader likely competes for food resources with both $H$. araneus and P. pubescens. As such, the presence of this invasive species could hold important consequences for trophic interactions, benthic ecosystem functioning and biodiversity. Microplastics were also found to be a likely stressor on this ecosystem, as $28 \%$ of all stomachs contained digested microplastics among other items. Long-term studies of benthic ecosystem structure and functioning are now needed to more fully understand the extent to which this new competitor may alter the future biodiversity of the Pechora Sea alongside the additional stressor of digested plastics.
\end{abstract}

Keywords Chionoecetes opilio $\cdot$ Pechora Sea $\cdot$ Stomach contents $\cdot$ Stable isotopes $\cdot$ Microplastics $\cdot$ Invasive species $\cdot$ Arctic Ocean $\cdot$ Benthic ecosystem

Supplementary Information The online version of this article (https://doi.org/10.1007/s00300-020-02775-3) contains

supplementary material, which is available to authorized users.

Anna Gebruk

Anna.Gebruk@ed.ac.uk

1 School of GeoSciences, University of Edinburgh, The King's Buildings, James Hutton Road, Edinburgh EH9 3FE, United Kingdom

2 Lomonosov Moscow State University Marine Research Center, Moscow, Russia

3 Shirshov Institute of Oceanology, Russian Academy of Sciences, Moscow, Russia

4 A.N. Severtsov Institute of Ecology and Evolution, Russian Academy of Sciences, Moscow, Russia

\section{Introduction}

\section{Pechora Sea ecosystems: conservation priorities and challenges}

Marine ecosystems of the Pechora Sea, in the south-eastern basin of the Barents Sea (Fig. 1), are characterised by a number of distinct features including relatively shallow water depths, significant impacts of continental runoff from the Pechora river, partial isolation from the open sea, a relatively short ice-free period, and a historically low level of anthropogenic activities (Nikiforov et al. 2005; Sukhotin et al. 2019). Several areas in the Pechora Sea have more recently been selected as components of a network of conservation priority areas in the Russian Arctic 
due to their importance as feeding grounds for seabirds and marine mammals (Spiridonov et al. 2017; Denisenko et al. 2019a; Gebruk et al. 2020). However, rapid increases in human activities such as oil and gas extraction, shipping, tourism, combined with climate change, introduction of invasive species and the release of contaminants are predicted to have a cumulative impact on the unique marine ecosystems of the Pechora Sea (Sukhotin et al. 2019; Semenova et al. 2019). Recent assessments of the current state and future challenges of the Pechora Sea ecosystems (Sukhotin et al. 2019) highlighted the importance of biodiversity studies in providing baseline data for future conservation and sustainable management activities in the region. In particular, investigations of food webs and trophic relationships between species are important for better understanding of biodiversity and broader ecosystem functioning.

\section{Ecological and trophic niche of benthic decapods}

Benthic decapod crustaceans are globally distributed and play an important role in benthic ecosystems and in fisheries, especially in the Arctic region where fisheries are expanding as climate change and sea ice losses accompany ecosystem shifts (Grebmeier 2012; Kolts et al. 2013). Whilst commercially fished populations of some circumpolar benthic decapod species including the snow crab Chionoecetes opilio have been studied in detail within the harvested distribution range, their diets and trophic roles remain less understood (Divine et al. 2017). Early studies on cold-water crab feeding indicate that they are opportunistic feeders, consuming the most abundant benthic organisms, though usually one food group/species dominates their diet and this varies regionally (Kun and Mikulich 1954; Kulichkova 1955; Cunningham 1969; Tarverdieva 1981; Jewett et al. 1989).

Diets are often used to determine ecological niches with various indices available to estimate niche overlaps, such
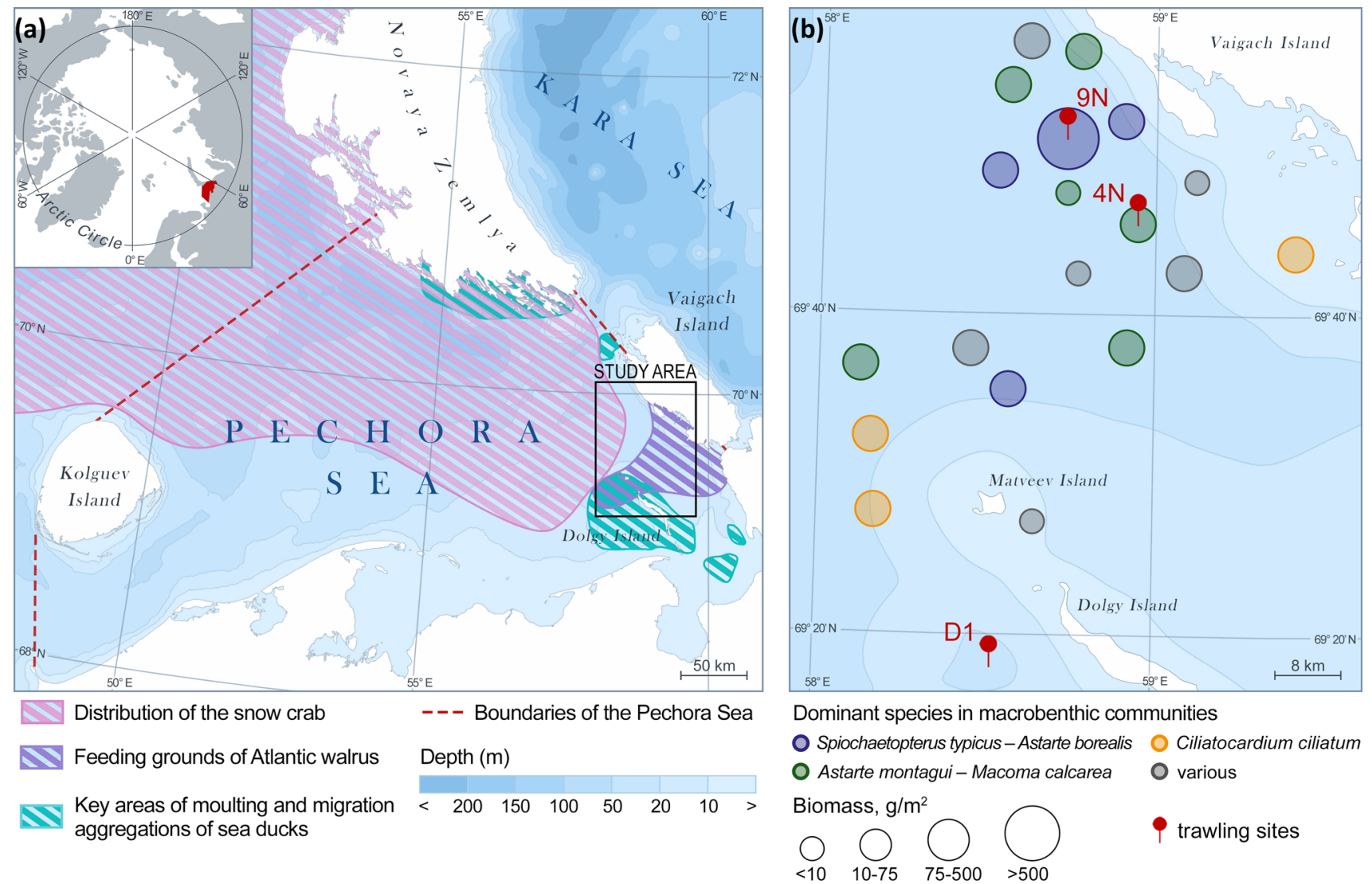

Fig. 1 a Overview map showing position of the study area in the Pechora Sea and in the broader Arctic. Pink dashing shows distribution of the snow crab in the research area (Lorentzen et al. 2018); purple dashing marks feeding grounds of Atlantic walruses (Semenova et al. 2019; Gebruk et al. 2020); green dashing corresponds to the key moulting and migrating areas of sea ducks (Sukhotin et al. 2008). b Detailed map of the sampling area: trawling sites are shown with red pins; circles of different colours represent biomass of dominant species in macrobenthic communities (Gebruk et al. 2020) 
as the Pianka's measure, MacArthur and Levins' measure, Morista's measure and others (Kerbs et al. 2017). Similarly, the composition of stable isotopes of carbon and nitrogen in animal tissues is used in feeding ecology as an emergent property of dietary niches and habitat use (Post 2007; Flaherty and Ben-David 2010). This is because carbon/nitrogen ratios in the tissues of aquatic organisms provide information on the source of feeding $\left(\delta^{13} \mathrm{C}\right)$ and relative trophic position $\left(\delta^{15} \mathrm{~N}\right)$ (Linnebjerg et al. 2016; Odintsov and Kiyashko 2018). The term 'isotopic niche' (Newsome et al. 2007) is broadly used in stable isotope analyses. It is defined as an area in $\delta^{13} \mathrm{C} / \delta^{15} \mathrm{~N}$ space that characterises the trophic resources and habitat use of the species.

In the present study, we compared overlap in dietary niches determined by stomach content analyses with overlap in isotopic niches based on stable isotope analysis to gain a better understanding of the trophic relationships between the three benthic decapod species in the Pechora Sea: the invasive snow crab Chionoecetes opilio and two native benthic crustaceans, the spider crab Hyas araneus and the hermit crab Pagurus pubescens. These three decapod species now form a guild of predators/scavengers at the top of the food web in the benthic ecosystem of the Pechora Sea.

\section{Distribution and diets of $C$. opilio, $H$. araneus and $P$. pubescens}

The snow crab $C$. opilio is a stenothermal brachyuran species broadly distributed in the northern Pacific and northern Atlantic Oceans, but in the Pechora Sea, it is an alien invasive species (Alvsvåg et al. 2009; Sokolov et al. 2016; Mullowney et al. 2018; Zalota et al. 2018). C. opilio was first recorded in fisheries bycatch in the Barents Sea near Gusinaya Banka in 1996, thereafter forming a self-maintained population; however, it was not deliberately introduced to the area (Jørgensen and Spiridonov 2013; Sokolov et al. 2016; Mullowney et al. 2018). It is a boreal Arctic coldwater species, typically inhabiting muddy sand grounds in waters 150-250 m deep in the Barents Sea (Bakanev et al. 2016). Average commercial size for male $C$. opilio in the Barents Sea is $113.8 \mathrm{~mm}$ carapace length (CL) and $58.7 \mathrm{~mm}$ carapace width (CW) (Bakanev and Pavlov 2019). In the Pechora Sea, C. opilio is most abundant near the Yuzhny Island of Novaya Zemlya archipelago (Zalota et al. 2018), where water masses are influenced by cold Arctic water from the Kara Strait (Bakanev et al. 2016; Zalota et al. 2018).

Several previous studies on diets of $C$. opilio were mostly conducted in Atlantic Canada (Miller 1981; Brethes et al. 1982; Wieczorek and Hooper 1995; Squires and Dawe 2003), with some studies in the Pacific Arctic (Chuchukalo et al. 2011; Divine et al. 2017), the North Pacific (Tarverdieva 1981; Nadtochiy et al. 2004), and in the Barents Sea (Manushin et al. 2016; Zakharov et al. 2018). Studies on
C. opilio diets have all reported diverse diets and the main food items varying between locations: polychaetes and crustaceans near the northeastern Newfoundland shelf (Squires and Dawe 2003); polychaetes and bivalves near the east coast of Newfoundland (Miller 1981); and fish near Bonne Bay, off the west coast of Newfoundland (Wieczorek and Hooper 1995). In this last case, authors hypothesised scavenging of discarded bait as the main foraging activity of snow crabs (Wieczorek and Hooper 1995). In the Barents Sea, adult males live deeper and consume more polychaetes and crustaceans that are more dominant on bank slopes. Females and subadult males show significant consumption of molluscs dominant in shallower areas, which they mostly inhabit (Zakharov et al. 2018). Most early studies agree on polychaetes, molluscs, crustaceans and echinoderms being present in diets of snow crabs, but with variable frequencies of occurrence in stomachs depending on species composition of the local macrobenthos.

The great spider crab Hyas araneus is a benthic decapod species widely distributed in the boreal North Atlantic and adjacent Arctic seas (d'Udekem d'Acoz 1999). It is the most common native brachyuran crab in the Barents Sea found in intertidal, upper and lower subtidal zones (Kuznetsov 1964; Zimina et al. 2015). The hermit crab P. pubescens is an Arctic-Boreal species, also common in the Barents Sea. It usually dwells in the shells of Buccinum, Neptunea and other gastropods, and is relatively small in size compared to both $C$. opilio and $H$. araneus, its body length not exceeding 100 mm (Gaevskaya 1948; d'Udekem d'Acoz 1999).

The diets of $H$. araneus and $P$. pubescens have not been extensively studied. $H$. araneus is known as a predator, very rarely consuming food items of plant origin, but more actively feeding on a broad range of benthic, hyperbenthic and planktonic animals. These include hydroids, loricates, gastropods, bivalves (including juveniles of scallops and mussels), amphipods, copepods, euphausiids, small crabs, sea stars, brittle stars, juvenile sea urchins and fishes (Squires 1990; Arsenault and Himmelman 1996; Fagerli et al. 2013; Pushkina 2017). Fatty acid studies in Spitsbergen showed that $H$. araneus in that region consume mostly benthic seston-feeding invertebrates (Paar et al. 2019) and even zooplankton (Legeżyńska et al. 2014). These food sources were also indicated by stable isotope analysis of the trophic status of this species in the southern Barents Sea fjords (Zalota 2017; Spiridonov et al. 2020).

In the Atlantic waters off Canada, $P$. pubescens is known to feed on phytobenthos, foraminifera, amphipods, ostracods, hydroids, fragments of bivalves, polychaetes and brittle stars (Squires 1990). In the Kongsfjord of Spitsbergen (Paar et al. 2019) and the fjords of the southern Barents Sea (Zalota 2017; Spiridonov et al. 2020), $P$. pubescens occupies a somewhat lower trophic level than $H$. araneus. There is also evidence that $P$. pubescens can 
consume plant material of terrestrial origin in the areas of abundant ornithogenic coastal vegetation in Spitsbergen (Zmudczyńska-Skarbek et al. 2015).

\section{Macrobenthos of the Pechora Sea: foraging resources for benthic decapods}

Macrobenthic communities of the Pechora Sea that form the bulk of benthic decapod diets in the study area are generally well described in the literature from the 1920 s (Brotskaya and Zenkevich 1939) with more detailed surveys conducted in the 1990s (Denisenko et al. 2003; Kucheruk et al. 2003). Macrobenthos of the Pechora Sea are characterised by very high spatial variability in terms of species composition and biomass, their distribution being controlled by substrate type, bottom topography and larger scale oceanographic regimes (Denisenko et al. 2003). Average biomass of macrobenthos in the Pechora Sea ranges from 1.5 to $536 \mathrm{~g}$ wet weight per $\mathrm{m}^{2}$ (Denisenko et al. 2003). The shallows of Pechora Bay are characterised by particularly low biomass (Gebruk et al. 2019; Denisenko et al. 2019b), whilst the north-western parts near the Novaya Zemlya and Vaygach Islands have the highest values of biomass of macrobenthic invertebrates in the Pechora Sea with largest contributions formed by bivalve molluscs Astarte borealis, Ciliatocardium ciliatum, Serripes groenlandicus, Nicania montagui and Macoma calcarea (Denisenko et al. 2019a; Gebruk et al. 2020). The presence of $C$. opilio and predation on benthic invertebrates may have an impact on the structure of these macrobenthic communities in the Pechora Sea, and may also go on to affect the availability of benthic feeding resources for seabirds (i.e. common eiders and other sea ducks) and marine mammals that forage on the benthos here including Atlantic walrus (Odobenus rosmarus; Gebruk et al. 2020) of the endangered Pechora Sea population (walrus listed as Vulnerable in the International Union for Conservation Red List, IUCN 2016).

\section{Objectives and expectations of this study}

Despite growing scientific and industrial attention on the Pechora Sea, our understanding of the Pechora Sea food web and trophic relationships between species remains limited, and in particular, the extent to which the spread of C. opilio may impact these relationships and alter biodiversity. When assessing diet composition and trophic niches of the three decapod species in this study, we expected $H$. araneus and $P$. pubescens to occupy distinct feeding niches due to their assumed long species co-existence and food resource partitioning (similar processes of niche separation have been described in some other decapod assemblages, e.g. Cartes 1998). At the same time, we expected the invasive species, $C$. opilio, to occupy overlapping dietary niches with $H$. araneus and $P$. pubescens as result of interference competition with the native decapods (Boudreau and Worm 2012). Combination of diet assessment with stable isotopic analysis used in this study is aimed to improve understanding of ecological and trophic niche of $C$. opilio in the Pechora Sea and inform future management and policy decisions leading to prevention of potential trophic shifts and biodiversity loss in the region.

\section{Methods}

\section{Study area}

Samples were collected during the R/V Kartesh cruises to the Pechora Sea in 2017-2018 in the area between the Vaygach and Matveev Islands in the south-western part of the sea at the depth range 18-39 m (Fig. 1). The study area lies within the important feeding grounds of Atlantic walruses (Semenova et al. 2019; Denisenko et al. 2019a; Gebruk et al. 2020), and marine duck species, including kind eiders, black and velvet scoters (Sukhotin et al. 2008). According to previous benthic surveys, macrobenthos in the area is formed by diverse communities of 133 species of invertebrates (Gebruk et al. 2020). Macrobenthic biomass is predominately formed by bivalve astartid molluscs (with the biggest contributions from Astarte borealis, Astarte montagui and Ciliatocardium ciliatum), but it varies greatly ranging from $32 \mathrm{~g} \mathrm{~m}^{-2}$ (site $4 \mathrm{~N}$ ) to $500 \mathrm{~g} \mathrm{~m}^{-2}$ (site 9 N) (Gebruk et al. 2020) (Table 1, Fig. 1). Presence of the decapod species C. opilio, H. araneus and P. pubescens in the research area was previously noted based on remotely operated vehicle (ROV) video footage (Gebruk et al. 2020), but their diets and trophic roles have not been studied. Bottom sediments are mostly homogeneous and formed by silty sands (Denisenko et al. 2019a; Gebruk et al. 2020).

\section{Sample collection}

Samples of benthic decapods for this study were collected from two sites in 2017 ( $9 \mathrm{~N}$ and $4 \mathrm{~N}$ ) and three sites in 2018 (9 N; 4 N; D1) using a Sigsbee bottom trawl with a $1.5-\mathrm{m}$ length frame and $0.5 \mathrm{~mm}$ mesh, manufactured in the Shirshov Institute of Oceanology, Moscow. Trawling was conducted at 2 knots for 30 min corresponding to a linear $1.85 \mathrm{~km}$ transect.

Bottom sediments from trawl catches were washed over a $0.5 \mathrm{~mm}$ mesh with seawater. Individuals of the decapod 
Table 1 Positions of trawling sites (taken at the beginning of a transect), depths and key characteristics of macrobenthic communities: biomass $\left(\mathrm{g} \mathrm{m}^{-2}\right)$, number of species, dominant species

\begin{tabular}{|c|c|c|c|c|c|c|}
\hline Site no. & Coordinates & and decimal minutes) & Depth (m) & Biomass $\left(\mathrm{g} \mathrm{m}^{-2}\right)$ & $\begin{array}{l}\text { Number of spe- } \\
\text { cies }\end{array}$ & Dominant species \\
\hline $9 \mathrm{~N}$ & N69;50.727' & E058;45.804' & 39 & 522.78 & 45 & Astarte borealis \\
\hline $4 \mathrm{~N}$ & N69;45.635' & E058;57.347' & 28 & 32.28 & 49 & Astarte montagui \\
\hline D1 & N69;17.809' & E58;30.986' & 18 & $\mathrm{n} / \mathrm{a}$ & $\mathrm{n} / \mathrm{a}$ & $\mathrm{n} / \mathrm{a}$ \\
\hline
\end{tabular}

species $C$. opilio, H. araneus and P. pubescens were then manually extracted and preserved for the further analyses. Individuals used for stomach content analysis (collected in 2017) were preserved in $4 \%$ formaldehyde solution, and then dissected in a laboratory. Extracted stomachs were transferred into $70 \%$ ethanol. Individuals used for isotopic analyses (collected in 2018) were measured and frozen at $-20^{\circ} \mathrm{C}$. All crabs were thawed, blotted with paper filters, and weighed prior to dissecting to the nearest $0.01 \mathrm{~g}$ (wet weight). Their sex was identified and carapace length (CL) and width $(\mathrm{CW})$ were measured to the nearest $0.01 \mathrm{~mm}$ with digital Vernier calipers (data provided in supplementary material, Online Resource 1).

\section{Stomach content analysis}

Seventy-five decapods collected in 2017 were used for stomach content analyses, of which 23 were $C$. opilio, nine were $H$. araneus and 43 were $P$. pubescens. Stomachs were dissected and their contents visually examined under a stereomicroscope. All items found in stomach contents were categorised into prey items (digestible remains of animals, unidentified organic debris) and other items. Prey items were identified to the lowest possible taxonomic level. Partly digested matter with no preserved hard structures that could be used for species identification were divided into 'plant debris' (remains of algae or aquatic plants with structures like blades or rhizoids) and 'organic debris' (digested amorphous material or detritus). Inclusions included sand, feathers and microplastics. Microplastics were defined as non-digested fibres or particles $<5 \mathrm{~mm}$ in length made of firm synthetic materials, often brightly coloured (Avio et al. 2017).

Food lump analysis was carried out following Burukovsky (2009). For each stomach, level of fullness was estimated visually and only stomachs that were $>25 \%$ full were used for food lump reconstructions. For each item in a stomach (prey items only), the percentage volume in the food lump was estimated visually. Based on average percentage volumes, a so-called 'virtual food lump' (Burukovsky 2009) was then reconstructed for each species to characterise diets. Besides level of fullness and prey species composition, other indices included: (1) dominance (as percentage of stomachs where a single prey item comprised $>60 \%$ of the food lump of all stomachs of species) and (2) mean number of prey items per stomach for each species. In addition, a matrix of presence-absence of each prey item in each stomach was constructed. Presence-absence data were used to calculate frequencies of occurrence of each stomach content component in diets of each species (as percentage of stomachs where this item was present).

To assess the predicted number of species in the diet of each species of decapod, species accumulation curves were calculated using the species richness $(S)$ of diet components with the Chao-2 type estimator as the following:

$\tilde{S}=S_{o b s}+\frac{(H-1) s_{1}^{2}}{2 H s_{1}}$

where $H=$ samples, $S_{\text {obs }}=$ the total number of observed species (diet components) and $S_{l}=$ the number of species (diet components) found in exactly one stomach.

Pianka's overlap measure (Pianka 1974) was used to assess overlaps in feeding niches based on frequencies of occurrence of feeding items following Krebs (1998):

$O_{j k}=\frac{\sum_{i}^{n} p_{i j} p_{i k}}{\sqrt{\sum_{i}^{n} p_{i j}^{2} \sum_{i}^{n} p_{i k}^{2}}}$,

where $=O_{j k}$ is the Pianka's measure of niche overlap between species $j$ and species $k,=p_{i j}$ proportion resource is one of the total resources used by species $j$ (occurrence of feeding item) $;=p_{i k}$ proportion resource is one of the total resources used by species $k ; n=$ total number of resources (feeding items).

To assess the relationships between the three species diets in more detail, we used the non-metric multidimensional scaling (nMDS) based on the Bray-Curtis similarity index and cluster analysis based on an unweighted pair group method with arithmetic mean (UPGMA) algorithm. Similarity of percentages (SIMPER) analyses was then carried out to assess contributions to differences between diets of different species. A pairwise analysis of similarities (ANOSIM) was performed, yielding pairwise comparisons of these and their associated $p$ values, with sequential Bonferroni corrections applied. All statistical calculations were performed 
using free statistical software PAST version 3.22 (Hammer and Harper 2006).

\section{Stable isotope analysis}

In August 2018, specimens of decapods were collected for stable isotope analysis at three stations in the Pechora Sea ( $9 \mathrm{~N}, 4 \mathrm{~N}$ and D1, Fig. 1). Muscle tissue from their claws was extracted in the laboratory and dried in plastic vials at $70{ }^{\circ} \mathrm{C}$ for 3 days. Dry tissue was then crushed into powder using a pestle and mortar and packed in tin foil (200-500 $\mu \mathrm{g}$ each). The isotopic analysis was carried out using a Thermo Delta V Plus isotope ratio mass spectrometer and Thermo Flash1112 element analyser at the Center for Collective Use at the Severtsov Institute of Ecology and Evolution of the Russian Academy of Sciences (SIEE RAS).

The ratios of the stable isotopes of carbon and nitrogen $\left({ }^{13} \mathrm{C} /{ }^{12} \mathrm{C}\right.$ and $\left.{ }^{15} \mathrm{~N} /{ }^{14} \mathrm{~N}\right)$ are presented in the delta per mille notation $(\delta, \% o)$ relative to international standards (VPDB for $\delta^{13} \mathrm{C}$ and atmospheric $\mathrm{N}_{2}$ for $\delta^{15} \mathrm{~N}$ ). The analytical error in determining the isotope composition (SD in the laboratory standard analysis, $n=6$ to 8 ) did not exceed $0.2 \%$. The $\delta^{13} \mathrm{C}$ values have been corrected for lipid concentration according to Post et al. (2007, their formula 3) for samples with mass $\mathrm{C} / \mathrm{N}$ ratio higher than four.

Data were tested for normality using Shapiro-Wilk test and Levene's test for homogeneity to confirm if parametric tests can be used for further comparison. Differences in the isotopic signatures $\left(\delta^{13} \mathrm{C}\right.$ and $\left.\delta^{15} \mathrm{~N}\right)$ of the three decapod species used in this study were tested using analysis of variance (ANOVA) with species and sampling area as factors. Isotopic niche parameters were calculated using the Stable Isotope Bayesian Ellipses in R (SIBER) package (Jackson et al. 2011) using RStudio (RStudio Team 2016; R Core Team 2018). The area of standard ellipses corrected for small sample size $\left(\mathrm{SEA}_{\mathrm{C}}\right)$ and their posterior estimates $\left(\mathrm{SEA}_{\mathrm{B}}\right)$ were used to compare individual species. The overlap of $\mathrm{SEA}_{\mathrm{C}}$ (including $95 \%$ of the data) was used to discuss isotopic niche proximity of different species. These overlaps were compared to the posterior distribution of $\mathrm{SEA}_{\mathrm{B}}$ overlaps to control for sample size errors. The overlap was reported as the proportion of the non-overlapping area (the total overlap area divided by the sum of the areas of two ellipses minus the total overlap area in $\% o^{2}$ ).

\section{Results}

\section{Stomach content analysis}

Collected crabs were a mixture of males and females with a predominance of males in all three species: 13 males and 10 females of C. opilio; 7 males and 2 females of $H$. araneus;
32 males and 11 females of $P$. pubescens (Supplementary material, Online Resource 1). All C. opilio were smaller than the average size of commercially exploited adults in the Barents Sea (113.8 mm CL, Bakanev and Pavlov 2019). Noticeably $C$. opilio and $H$. araneus were of a similar size group: C. opilio average $\mathrm{CL}$ was $32.0 \pm 3.75 \mathrm{~mm}$, ranging from 27 to $32 \mathrm{~mm}$; $H$. araneus average CL was $47.0 \pm 8.44 \mathrm{~mm}$ (28-58 $\mathrm{mm}$ ); and $P$. pubescens were 4-5 times smaller with $\mathrm{CL}$ of $8.5 \pm 2.62 \mathrm{~mm}(4.0-12.5 \mathrm{~mm})$.

Approximately $22 \%$ of all stomachs were empty or nearempty ( $<25 \%$ fullness), comprising two stomachs of $P$. pubescens (out of 43), three stomachs of $H$. araneus (out of 9) and 11 stomachs of $C$. opilio (out of 23). The rest contained prey items and were identified as full or near-full (>75\% fullness) or not empty (25-75\%) (supplementary material, Online Resource 1). All stomach contents reflected mixed diets with an average of 6 prey items $(5 \pm 1.8$ for $C$. opilio and $H$. araneus; $6 \pm 1.2$ for $P$. pubescens). Low value of dominance index (3\%) showed that few food lumps were dominated by only one prey item (excluding organic debris).

Nineteen categories of items were identified in stomach contents, 15 of which were classified as prey items. Twentyseven taxa of benthic invertebrates were identified (12 to species level, 5 to genus, rest to family or above). A full list of prey items is presented in Online Resource 2. With respect to species richness, bivalve molluscs, annelids and foraminifers were the most diverse groups, accounting for 5 to 6 taxa each. Most of the other taxonomic groups were represented by a single species or by unidentifiable fragments. Identified bivalves included Astarte elliptica, Mytilus edulis, Ciliatocardium ciliatum, Dacrydium vitreum, Ennucula tenuis and Macoma calcarea. Identified annelids (polychaetes) included Pectinaria sp., Nephtys sp., Owenia sp., Maldanidae, Cirratulidae and Aphroditiformia.

The most frequently occurring prey items in food lumps, excluding organic debris, were bivalve molluscs and annelids for $C$. opilio and H. araneus, in addition to plant debris for P. pubescens (Fig. 2). Crustaceans (amphipods or barnacles) were represented in $>10 \%$ of stomachs of each species, whilst the frequency of occurrence of all other prey items varied significantly between the three decapod species (Fig. 2). Food lumps of $H$. araneus had relatively small numbers of prey items (6 excluding detritus and inclusions), and each was present in $>10 \%$ of stomachs, as opposed to $P$. pubescens and $C$. opilio that had a larger variety of prey items (10 to 13) with variable frequencies of occurrence ranging from 2 to $83 \%$.

Noticeably, smaller animal taxa were more frequent in stomachs of $P$. pubescens than in other decapods. For example, foraminifers (Cibicides refulgens, Elphidium excavatum, Buccella frigida and others) were found in $37 \%$ of $P$. pubescens stomachs, $9 \%$ of $C$. opilio and $1 \%$ of $H$. araneus. Similarly, hydrozoans (Obelia sp. and others) were present 


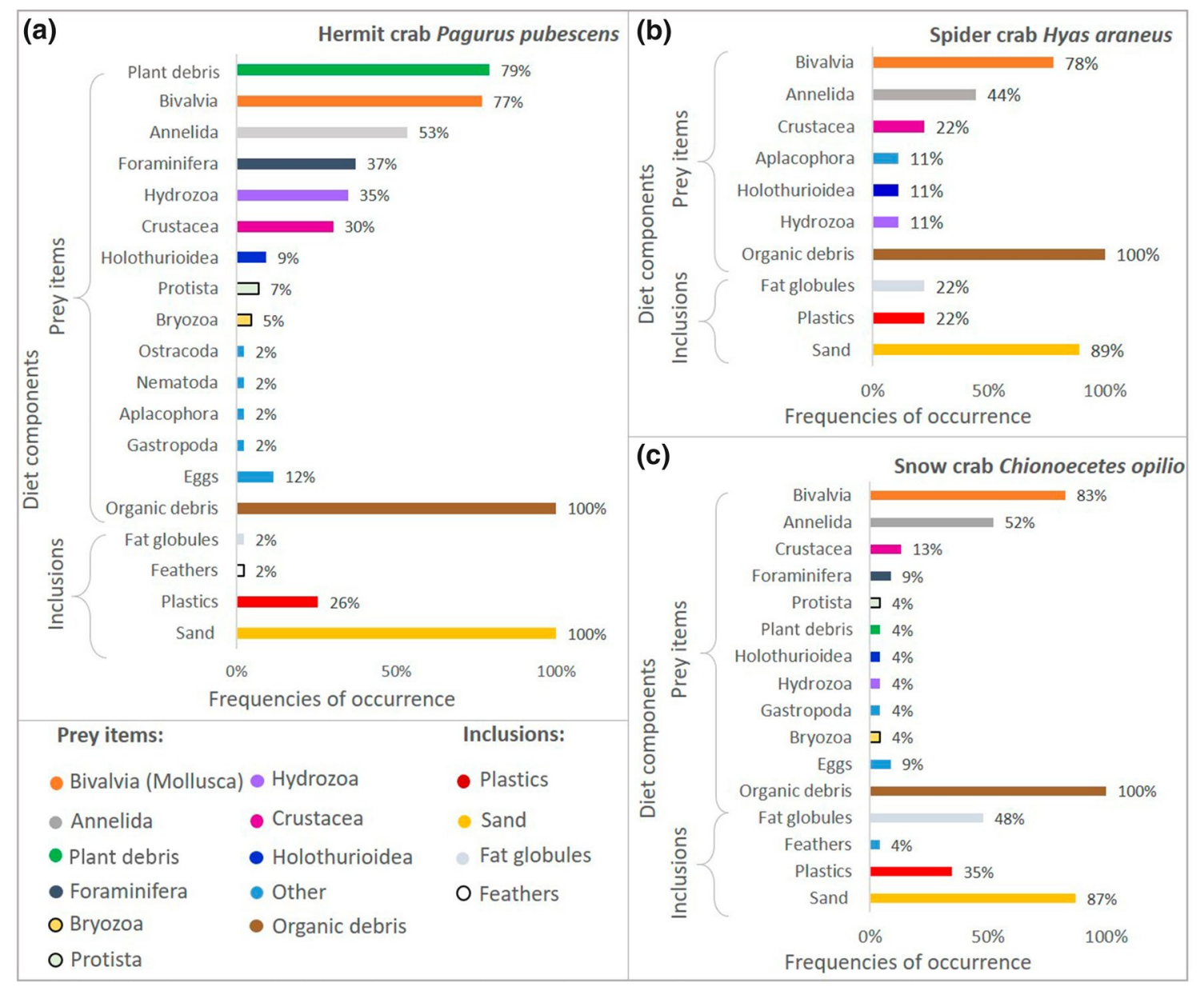

Fig. 2 Frequency of occurrence (\%) of diet components in stomachs of P. pubescens (a); H. araneus (b) and C. opilio (c)

in $35 \%$ of $P$. pubescens, $11 \%$ of $H$. araneus and only $4 \%$ of C. opilio. Nematodes and ostracods were only present in stomachs of hermit crabs.

Sand granules were present among the inclusions in the majority of stomachs of all species with a $92 \%$ average frequency of occurrence (ranging from $87 \%$ for C. opilio to $100 \%$ for P. pubescens). Microplastics occurred with 27\% average frequency, ranging from $22 \%$ for $H$. araneus to $35 \%$ for C. opilio (Online Resource 3). Organic debris appeared in all non-empty stomachs of all species (100\% frequency of occurrence). Similarly, organic debris played an important role in food lumps of all three species. However, its relative contribution to the total volume as well as contribution of other prey items and inclusions varied between species (Fig. 3).

In the food lump of $P$. pubescens, organic debris accounted for $70 \%$ of total volume, followed by sand granules (14\%), bivalve molluscs (6\%), plant debris (5\%), and other prey items that together only accounted for $3 \%$ of the volume. The food lump of $H$. araneus also consisted primarily of organic debris (58\% of the total volume), followed by bivalve mollusc (21\%), sand granules (12\%), polychaetes (7\%), with minor contributions from hydrozoans $(1 \%)$ and other groups (1\%). In contrast, bivalve molluscs (37\%) were key contributors to the total volume of the food lump of $C$. opilio followed by organic debris (36\%), sand (13\%), polychaetes (5\%), holothurians (5\%), and other groups (together accounting for $4 \%$ of the total volume).

Neither UPGMA hierarchical cluster analysis nor nMDS revealed strong differences between the three species. This shows that the diets of the three species overlap. It also appeared that $P$. pubescens tended to separate more from $C$. opilio and $H$. araneus than $C$. opilio and $H$. araneus between each other (Fig. 4). Sex and predator size did not affect diet composition as determined by cluster and nMDS analyses.

For all pairs of species, Pianka's measure (calculated for frequencies of occurrence of prey items) was close to 1.0 , representing almost full overlap in feeding resources. However, overlap between $C$. opilio and H. araneus (0.97) was higher than between $P$. pubescens and brachyuran crabs (0.75 for C. opilio-P. pubescens and $0.77 \mathrm{H}$. araneus $-P$. pubescens). Pairwise comparison of diets of the three 
Fig. 3 Food lumps with relative proportions (\%) of key prey items to total volume for $P$. pubescens (a) H. araneus (b) and C. opilio (c)
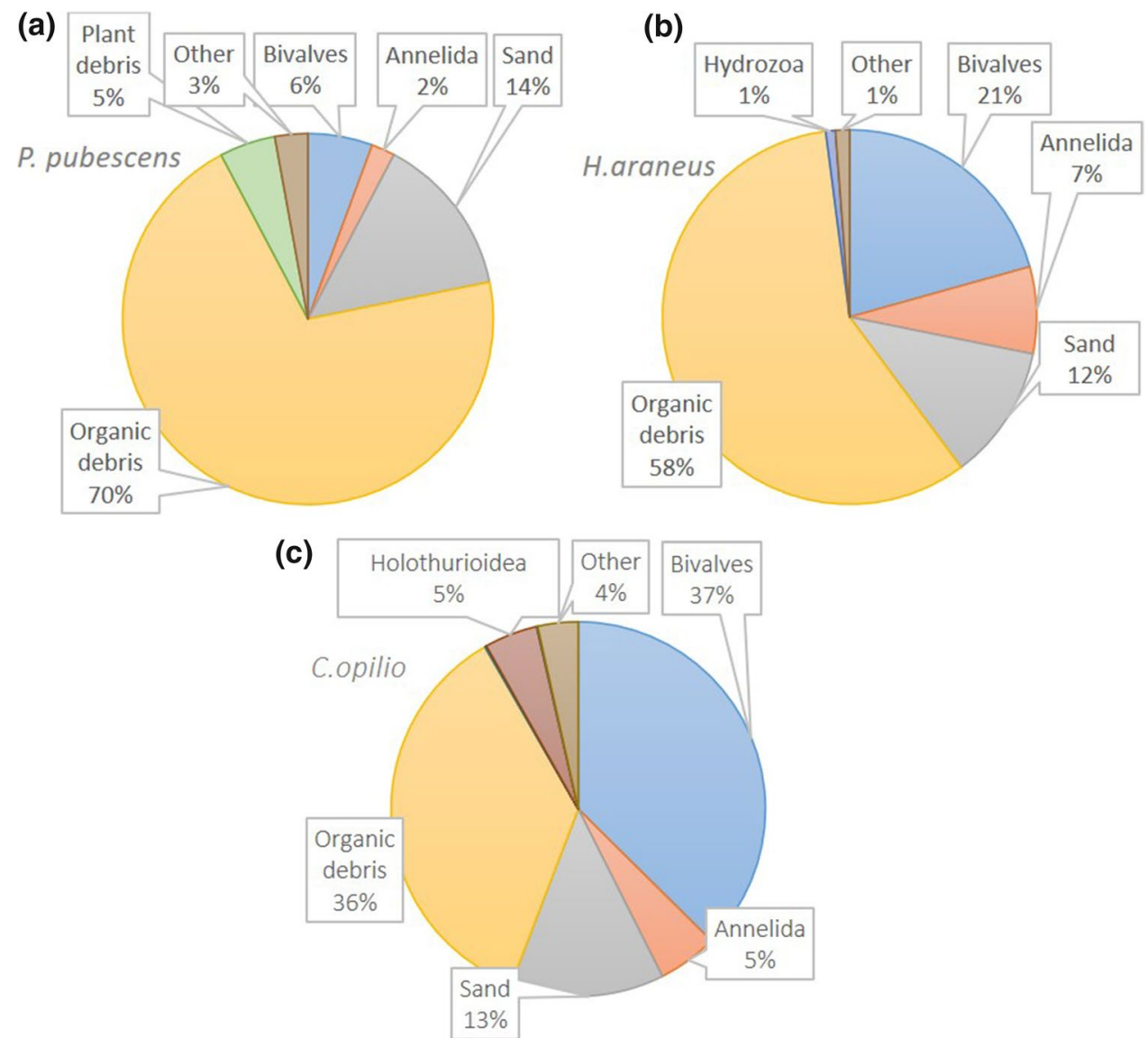

species using ANOSIM and Bray-Curtis similarity measure both agreed with Pianka's index suggesting close proximity between diets of $C$. opilio and $H$. araneus ( 0.67 similarity measure and no significant difference $(p>0.05)$ according to ANOSIM). However, they disagreed with the overlap measure in assessing the relationship between $P$. pubescens and other decapods: Bray-Curtis and ANOSIM showed low similarity and significant difference between $P$. pubescens and larger decapods (Table 2). Overall prey item compositions of $C$. opilio and $H$. araneus diets were close to each other, whilst stomach contents of $P$. pubescens were slightly different from both other species.

Species accumulation curves were used to assess cumulative numbers of prey items in the diets of the three species. The most diverse diet was in P. pubescens, comprising all 19 categories of discovered items, followed by $C$. opilio (16 categories) and $H$. araneus (11 categories). However, species accumulation curves showed that in fact $C$. opilio acquired diet components faster than two other species, with predicted increase in the number of stomachs increasing the number of prey items. This was confirmed by the Chao-2 estimator calculated for predicted total number of prey items. The expected values were: 33 for C. opilio, 18 for $H$. araneus and 27 for $P$. pubescens. Conversely, accumulation curves for $P$. pubescens were close to reaching a plateau

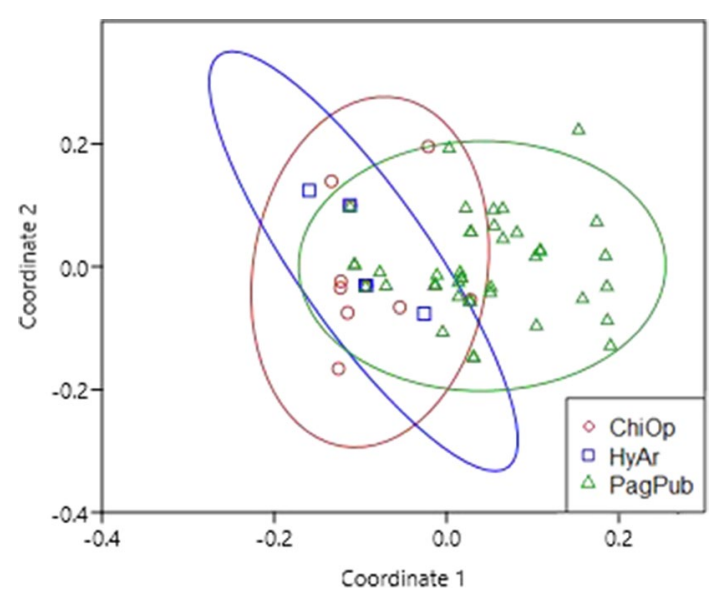

Fig. 4 Stomachs of different species grouped by the nMDS $(95 \%$ ellipses), calculated with Bray-Curtis similarity measure. Stomach of $C$. opilio-red circles; $H$. araneus-blue squares, $P$. pubescensgreen triangles

for the given number of stomachs (Fig. 5). Mean increment rate of the number food items was the highest for $C$. opilio, exceeding that both for $H$. araneus and $P$. pubescens at all the levels of sampling sets. These estimations confirm the 
Table 2 Pairwise comparison of diets of three species with Pianka's niches overlap measure; Bray-Curtis similarity measure and ANOSIM analysis ( $p<0.05$ showed with green shading)

\begin{tabular}{ll}
\hline & Index value \\
\hline Pianka's niches overlap index & \\
C. opilio-H. araneus & 0.97 \\
C. opilio-P. pubescens & 0.75 \\
H. araneus-P. pubescens & 0.77 \\
Bray-Curtis similarity measure & \\
C. opilio-H. araneus & 0.67 \\
C. opilio-P. pubescens & 0.27 \\
H. araneus-P. pubescens & 0.39 \\
ANOSIM (significance of difference based & \\
on Bray-Curtis similarity index) & \\
C. opilio-H. araneus & $p=0.39 ; R=0.01$ \\
C. opilio-P. pubescens & $p=0.001 ; R=0.81$ \\
H. araneus-P. pubescens & $p=0.004 ; R=0.46$ \\
\hline
\end{tabular}

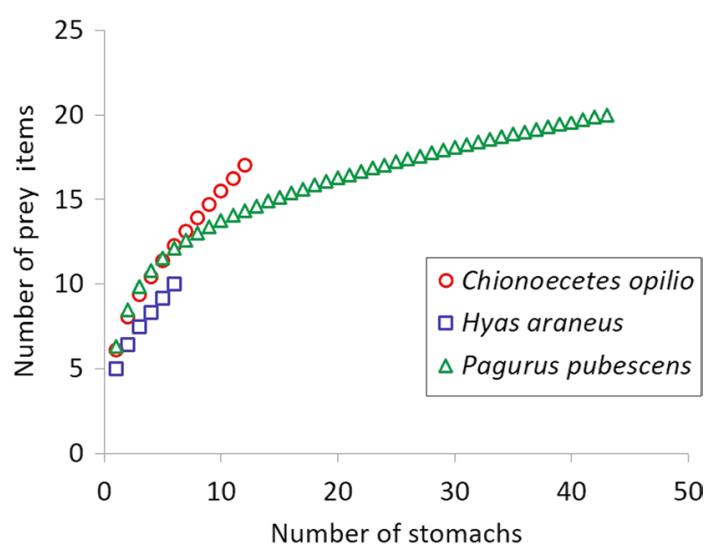

Fig. 5 Species accumulation curves of $C$. opilio-red circles; H. araneus - blue squares, $P$. pubescens-green triangles

wider trophic niche of newcomer $C$. opilio in comparison with native species.

Table 3 Number of specimens $(n)$, average $\delta^{13} \mathrm{C}$ and $\delta^{15} \mathrm{~N} \pm$ standard deviation (means, \%o), and ellipse's area corrected for small sample size $\left(\mathrm{SEA}_{\mathrm{C}}, \%^{2}\right)$ that includes $95 \%$ of the data. In brackets is the

\section{Stable isotope analysis}

Overall 40 decapods were used in stable isotope analysis of which 12 were $C$. opilio (six from Station $9 \mathrm{~N}$, five from $4 \mathrm{~N}$, and one from Station D1); $10 \mathrm{H}$. araneus (all from Station $4 \mathrm{~N}$ ); and $12 P$. pubescens (eight from Station $9 \mathrm{~N}$, eight from $4 \mathrm{~N}$, and two from Station D1) (Table 3). ANOVA showed differences in both $\delta^{13} \mathrm{C}$ and $\delta^{15} \mathrm{~N}$ when the samples from different areas were pooled as one (Table 4). The data were not normally distributed allowing the use of ANOVA (Shapiro-Wilk test; $p>0.05$ ) and homogenous (Levene's test, $p>0.05$ ). When parametric tests and SIBER analysis were performed on the data with sample area differences, the three crabs from nearby Dolgy Island (D1) were excluded due to low sample size (resulting in 37 crabs in total). ANOVA revealed differences in both $\delta^{13} \mathrm{C}$ and $\delta^{15} \mathrm{~N}$ between species and area, as well as an interaction among species and area for $\delta^{15} \mathrm{~N}$ data (Table 4).

Tukey's HSD test revealed differences in $\delta^{13} \mathrm{C}$ between $H$. araneus versus $C$. opilio, and $H$. araneus versus $P$. pubescens $(p<0.05)$; and a difference only between $C$. opilio and $P$. pubescens in $\delta^{15} \mathrm{~N}$ (Table 5) in both ANOVA tests. In addition, Tukey's HSD test of the two-way ANOVA revealed differences between $H$. araneus with other decapod species in $\delta^{13} \mathrm{C}$, and general difference between two areas and $P$. pubescens between the areas and with $C$. opilio for $\delta^{15} \mathrm{~N}$ data (Table 5).

The area of ellipses that incorporated $95 \%$ of the data, corrected for small sample size $\left(\mathrm{SEA}_{\mathrm{C}}\right)$, are reported in Table 4 and presented in Fig. 6. Most of SEA $_{C}$ were very similar to posterior estimate $\left(\mathrm{SEA}_{\mathrm{B}}\right)$ except for the $P$. pubescens from $9 \mathrm{~N}$ where the mean $\mathrm{SEA}_{\mathrm{B}}$ was twice the size of $\mathrm{SEA}_{C}$; however, the mode $\operatorname{SEA}_{B}(0.34)$ was somewhere between the two (which could be seen as a result of limited sample size and should be considered with caution). The proportion overlap of isotopic niches is presented in Table 6. The lowest overlap was between $H$. araneus and $P$. pubescens without area differentiation (0.08) and even more so when $P$. pubescens only from $4 \mathrm{~N}$ was considered (0.03).

average ellipse area of posterior estimate $\left(\mathrm{SEA}_{\mathrm{B}}\right)$ for $P$. pubescens from $9 \mathrm{~N}$ (the only posterior estimate that was more than $0.02 \% o^{2}$ different from $\mathrm{SEA}_{\mathrm{C}}$ )

\begin{tabular}{|c|c|c|c|c|c|c|c|c|c|}
\hline & \multicolumn{3}{|c|}{ All (9 N, 4 N, D1) } & \multicolumn{3}{|c|}{$9 \mathrm{~N}$} & \multicolumn{3}{|c|}{$4 \mathrm{~N}$} \\
\hline & $n$ & Means & $S E A_{C}$ & $n$ & Means & $S E A_{C}$ & $n$ & Means & $S E A_{C}$ \\
\hline C. opilio & 12 & $\begin{array}{l}-20 \pm 0.3 \\
12.5 \pm 0.4\end{array}$ & 0.46 & 6 & $\begin{array}{l}-20 \pm 0.3 \\
12.7 \pm 0.3\end{array}$ & 0.33 & 5 & $\begin{array}{l}-19.8 \pm 0.4 \\
12.4 \pm 0.3\end{array}$ & 0.50 \\
\hline H. araneus & 10 & $\begin{array}{l}-20.5 \pm 0.3 \\
12.3 \pm 0.5\end{array}$ & 0.36 & & & & 10 & $\begin{array}{l}-20.5 \pm 0.3 \\
12.3 \pm 0.5\end{array}$ & 0.36 \\
\hline P. pubescens & 18 & $\begin{array}{l}-19.8 \pm 0.3 \\
11.9 \pm 0.5\end{array}$ & 0.42 & 8 & $\begin{array}{l}-20 \pm 0.5 \\
11.5 \pm 0.5\end{array}$ & $0.27(0.47)$ & 8 & $\begin{array}{l}-19.7 \pm 0.2 \\
12.4 \pm 0.3\end{array}$ & 0.15 \\
\hline
\end{tabular}

All data include samples from D1 sampling area 
Table 4 Results of ANOVA test for data pooled by species with no area differentiation (pooled data) and two-factor ANOVA with species and area difference; as well as Shapiro-Wilk normality test and Levene's test for homogeneity results for both types of ANOVA for $\delta^{13} \mathrm{C}$ and $\delta^{15} \mathrm{~N}$ data

\begin{tabular}{|c|c|c|c|c|c|c|c|c|}
\hline & \multicolumn{3}{|c|}{ ANOVA } & \multicolumn{2}{|c|}{$\begin{array}{l}\text { Shapiro-Wilk } \\
\text { normality test }\end{array}$} & \multicolumn{3}{|c|}{$\begin{array}{l}\text { Levene's test for } \\
\text { homogeneity }\end{array}$} \\
\hline & $D f$ & $F$ & $p$ & $W$ & $p$ & $D f$ & $F$ & $p$ \\
\hline \multicolumn{9}{|l|}{$\delta^{13} \mathrm{C}$} \\
\hline Pooled data & 2 & 11.4 & 0.0001 & 0.97 & 0.33 & 2 & 0.43 & 0.65 \\
\hline \multicolumn{9}{|l|}{ Area differentiated data } \\
\hline By species & 2 & 13.1 & $6.80 E-05$ & 0.97 & 0.40 & 4 & 1.7 & 0.18 \\
\hline By sample area & 1 & 3.7 & 0.0644 & & & & & \\
\hline $\begin{array}{l}\text { Interaction species: area } \\
\delta^{15} \mathrm{~N}\end{array}$ & 1 & 0.2 & 0.6517 & & & & & \\
\hline Pooled data & 2 & 4.7 & 0.0153 & 0.97 & 0.46 & 2 & 0.6 & 0.55 \\
\hline \multicolumn{9}{|l|}{ Area differentiated data } \\
\hline By species & 2 & 7.2 & 0.0027 & 0.97 & 0.41 & 4 & 0.9 & 0.47 \\
\hline By sample area & 1 & 6.1 & 0.0189 & & & & & \\
\hline Interaction species: area & 1 & 12.8 & 0.0011 & & & & & \\
\hline
\end{tabular}

Statistically significant results $(\mathrm{p}<0.05)$ shown in italics
Similarly low overlap was found between $C$. opilio and $P$. pubescens at $9 \mathrm{~N}$.

Overall, stable isotope analysis showed a clear discrepancy of isotopic niches between $H$. araneus and P. pubescens, provided that within one station niches overlapped less than among all samples. The isotopic niches of $C$. opilio overlapped with both native decapod species to a greater extent.

\section{Discussion}

\section{Trophic niches of $C$. opilio, $H$. araneus and $P$. pubescens in the Pechora Sea}

From the present integrated study using both stomach contents and stable isotope analyses, it is clear that the diets

Table 5 Results with significant difference $(p<0.05)$ of Tukey's HSD test for two-factor ANOVA with species and area difference for $\delta^{13} \mathrm{C}$ and $\delta^{15} \mathrm{~N}$ data

\begin{tabular}{ll}
\hline & $p$ \\
\hline$\delta^{13} \mathrm{C}$ & \\
H. araneus vs. C. opilio & 0.0019 \\
H. araneus vs. P. pubescens & 0.0001 \\
H. araneus $4 \mathrm{~N}$ vs. C. opilio 4 N & 0.0149 \\
H. araneus $4 \mathrm{~N}$ vs. P. pubescens 4 N & 0.0002 \\
$\delta^{15} \mathrm{~N}$ & \\
P. pubescens vs. C. opilio & 0.0024 \\
$4 \mathrm{~N}$ vs. $9 \mathrm{~N}$ & 0.0372 \\
P. pubescens $9 \mathrm{~N}$ vs. C. opilio $9 \mathrm{~N}$ & 0.0001 \\
P. pubescens $9 \mathrm{~N}$ vs. P. pubescens $4 \mathrm{~N}$ & 0.0026 \\
\hline
\end{tabular}

and trophic niches of the three decapod species $C$. opilio, $H$. araneus and $P$. pubescens overlap substantially and over time if the density and distribution of $C$. opilio continue to grow, this could threaten the structure and functioning of the benthic Pechora Sea ecosystem. The overall however is not surprising, considering similar feeding habits and co-occurrence in the same feeding grounds, with all three decapods being benthic omnivores that forage on macrobenthic communities. Co-occurrence of the two native Barents Sea species (H. araneus and P. pubescens) was previously reported during a field observation experiment on scavenging behaviour of $H$. araneus near Spitsbergen (Svalbard). However, during that experiment, P. pubescens individuals were near the bait (cod) but no scavenging activity was observed, whereas $H$. araneus actively consumed the bait (Markowska et al. 2008). This can be considered as circumstantial evidence that $H$. araneus and $P$. pubescens do not share carrion prey.

It is also not surprising that stomach content and isotopic composition in the same species can vary between stations (such as $\delta^{15} \mathrm{~N}$ values in $P$. pubescens at $9 \mathrm{~N}$ and $4 \mathrm{~N}$ ), because macrobenthos of the Pechora Sea is highly variable over short spatial scales (Denisenko et al. 2003; Sukhotin et al. 2019). In the research area, the station $4 \mathrm{~N}$ is characterised by high biomass of macrobenthos with strong dominance of the bivalve mollusc $A$. borealis, whilst macrobenthos at station $9 \mathrm{~N}$ is formed by $A$. montagui-M. calcarea assemblage and characterised by low biomass (Gebruk et al. 2020).

Prey item composition of stomach contents showed that the diets of all three species consisted of bivalve molluscs and polychaetes with minor contributions from other taxa. Noticeably, the most frequent bivalve fragments in the stomachs (C. ciliatum, E. tenuis, M. calcarea and others) 
(a)

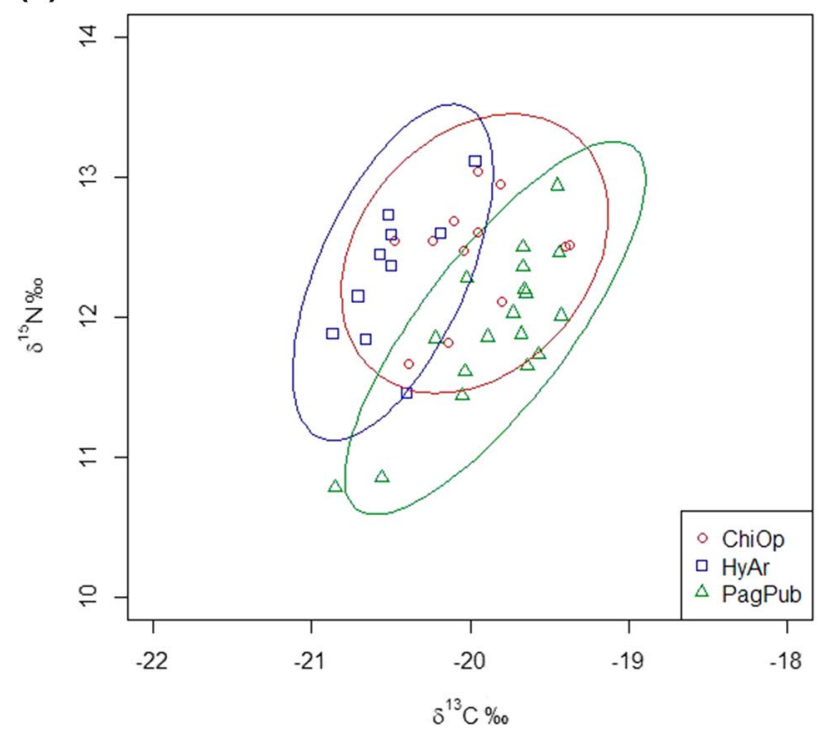

(b)

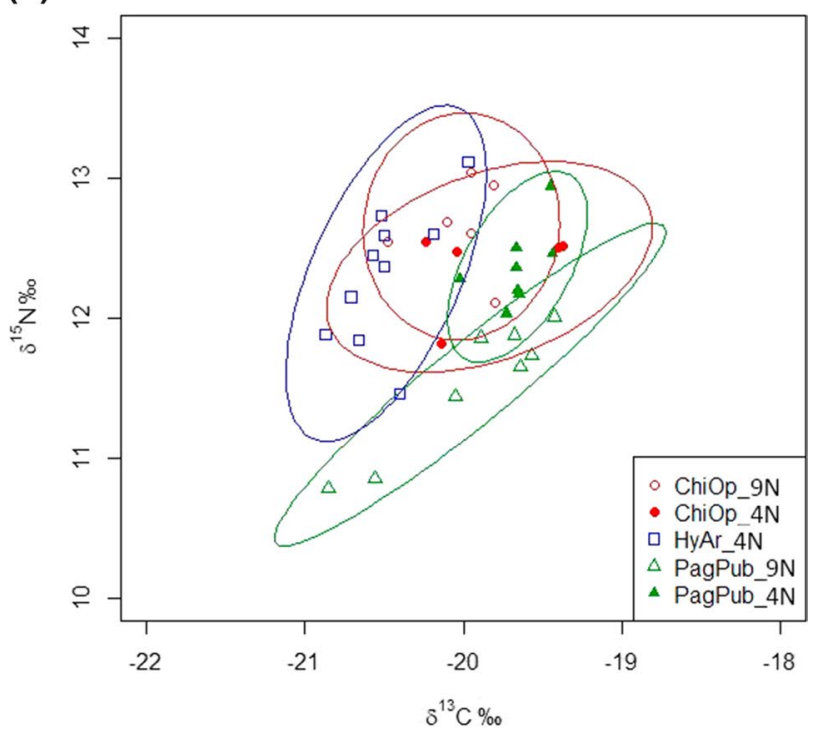

Fig. 6 Ellipses that incorporate $95 \%$ of the data, corrected for small sample size $\left(\mathrm{SEA}_{\mathrm{C}}\right)$ for a data not differentiated; $\mathbf{b}$ data differentiated by sampling area

Table 6 Overlap as the proportion of the non-overlapping area (the total overlap area divided by the sum of the areas of two ellipses minus the total overlap area in $\% o^{2}$ ) for data with and without area differentiation

\begin{tabular}{ll}
\hline & Overlap \\
\hline C. opilio and H. araneus & 0.35 \\
C. opilio and P. pubescens & 0.33 \\
H. araneus and P. pubescens & 0.08 \\
C. opilio $9 \mathrm{~N}$ and $4 \mathrm{~N}$ & 0.44 \\
P. pubescens $9 \mathrm{~N}$ and $4 \mathrm{~N}$ & 0.12 \\
C. opilio $9 \mathrm{~N}$ and P. pubescens 4 N & 0.04 \\
C. opilio $4 \mathrm{~N}$ and P. pubescens 4 N & 0.31 \\
C. opilio $4 \mathrm{~N}$ and H. araneus 4 N & 0.32 \\
P. pubescens $4 \mathrm{~N}$ and H. araneus $4 \mathrm{~N}$ & 0.03 \\
\hline
\end{tabular}

did not correspond exactly to the dominant macrobenthic species known for the area (A. borealis, A. montagui, $M$. calcarea, $S$. groenlandicus, $C$. ciliatum). We suspect that this is the result of limitations in taxonomic resolution of visual identification for stomach contents. Only fragments with preserved identifying features (usually hard structures) can be identified to the species level, whereas larger items including most of the bivalve species appear in the form of non-identifiable fragments, generally referred to as bivalve shells.

Observations of the food lumps revealed notable contribution of plant debris to diet compared to other species. This is in agreement with previous studies, i.e. ZmudczyńskaSkarbek et al. (2015) demonstrated that $P$. pubescens can consume plant material of terrestrial origin in the areas of abundant ornithogenic coastal vegetation in Spitsbergen. Our results show that even in the Pechora Sea, where aquatic vegetation is not abundant (Kucheruk et al. 2003), the diet of $P$. pubescens included a substantial proportion of plant debris.

The pairwise comparison of prey item composition of the three species using Pianka's overlap measure, Bray-Curtis similarity measure and ANOSIM test showed an overlap between the three species with stronger affinity of $C$. opilio and $H$. araneus diets, and slightly different stomach content in P. pubescens. We assume that those differences in diets are mainly attributed to the size of prey items as well as differences in claw morphology between Anomura (P. pubescens) and Brachyura (C. opilio and H. araneus). Relatively small sample size available for this study also needs to be taken in consideration and we suggest increasing sample size in the future for more in-depth analyses of the differences in diets of the three species.

The proportional overlap of isotope niches calculated as standard ellipses corrected for small sample size $\left(\mathrm{SEA}_{\mathrm{C}}\right)$ agrees with some but not all of the results from the ANOVA tests. The ANOVA suggested differences of $\delta^{13} \mathrm{C}$ between $H$. araneus and $C$. opilio both with and without area differentiation and $\delta^{15} \mathrm{~N}$ in P. pubescens and C. opilio without area differentiation and at $9 \mathrm{~N}$. The standard ellipse calculations took into account both $\delta^{13} \mathrm{C}$ and $\delta^{15} \mathrm{~N}$ data simultaneously whereas ANOVA does not. Therefore we believe that the overlap of $\mathrm{SEA}_{\mathrm{C}}$ is a better representation of the trophic niche partitioning by the species. 


\section{Limitations of the morphological analyses in feeding studies and further research questions}

Several morphological studies of stomach content pointed out limitations of this method. These include low taxonomic resolution and difficulty to assess relative importance of prey items. This is because many prey types remain underreported due to loss of distinctive diagnostic features as a result of digestion (Tarverdieva 1981; Squires and Dawe 2003). In addition, integrity of the shell fragments can cause bias towards greater contribution of bivalves in food lumps. This limitation of the present study is further complicated by relatively small (especially for Hyas araneus) and temporally restricted samples. Loss of data can also occur from empty stomachs, e.g. in our study $22 \%$ of stomachs were excluded from the analyses as empty or near-empty.

However, despite these shortcomings the morphological analysis still allows the assessment of a diversity of prey items in more details than the stable isotope analysis. The morphological analysis revealed that smaller prey items (including foraminifers, hydrozoans, ostracods, nematodes and others) played an important role in the diet of $P$. pubescens, whereas they were absent or scarce in diets of C. opilio and $H$. araneus. Larger items including bivalve molluscs Astarte borealis, Serripes groenlandicus and Ciliatocardium ciliatum are available for larger $C$. opilio and $H$. araneus, whilst smaller $P$. pubescens utilise more diverse but poorer in terms of size and biomass infauna. However, for C. opilio scooping sand was previously observed by Cunningham (1969) during periods when no larger food was immediately available. Logvinovich (1945) referred to the frequent presence of sediment in the stomachs and intestines of crabs. Foraminifera, minute molluscs and amphipods found in stomach contents probably result from feeding by sieving, as these either burrow in or occur on sediments (Logvinovich 1945).

Literature on the feeding of $C$. opilio also indicates frequent differences in diets of males and females, although this mostly refers to adult crabs (Wieczorek and Hooper 1995; Zakharov et al. 2018). The Pechora Sea however is predominantly populated by subadult males and females which do not differentiate in diets to the same degree (Bakanev et al. 2017) and thus we did not identify sex-related differences in diets in our samples of $C$. opilio.

\section{Microplastics ingestion by decapods in the Pechora Sea}

The analysis of inclusions in stomach contents revealed a considerable level of microplastic digestion by all three species. Microplastic particles were present in 35\% of $C$. opilio, 22\% of $H$. araneus and $26 \%$ of $P$. pubescens. All plastics were classified as microfibers or fragments following Michida et al. (2019). Chemical composition of microplastics was not assessed in the present study although should be addressed in the future specific studies of microplastic digestion to give a better understanding of potential sources of pollution. Consumed microplastics were previously reported for various marine invertebrates including crustaceans, such as the Norway lobster Nephrops norvegicus (Murray and Cowie 2011), brown shrimps Crangon crangon (Pott 2014), in the gut contents and haemolymph of the shore crab Carcinus maenas (Farrell and Nelson 2013) and others. Nevertheless, biological hazards and ecotoxicological effects of digestion of microplastics by marine fauna remain poorly understood. Increased concerns are related to potential adsorption and transport of pollutants through food webs and leaching of industrial additives (i.e. bisphenol A) that are known to have endocrine-disrupting effects (Avio et al. 2017). We suggest that the present study contributes to the knowledge on microplastics distribution and ingestion by benthic fauna. Further studies are needed to reveal the effects of plastics on benthic decapods with specific focus on the effects of digested plastics on the commercially harvested species C. opilio.

\section{Conclusions}

This study is based on analyses of stomach contents of 75 specimens and stable isotope analyses of 40 specimens of the three benthic decapod species from the Pechora Sea. The study suggests that the invasive snow crab C. opilio is in direct trophic competition with the spider crab $H$. araneus and the much smaller hermit crab $P$. pubescens, both of which are native to the Pechora Sea, with the potential to lead to species replacement. $H$. araneus and $P$. pubescens differed in $\delta^{13} \mathrm{C}$, suggesting different food sources, which could be a result of somewhat different prey species composition (i.e. substantial contribution of plant debris in stomach contents of the hermit crabs), and also prey size differences (larger prey items available for $H$. araneus) and differences in claw morphology. The invasive species $C$. opilio had an overlapping isotopic niche as well as overlapping stomach content composition with both of the native decapod species. To understand the extent to which the new competitor may alter the future biodiversity and ecosystem functioning of the Pechora Sea, a long-term study of biodiversity is now needed. This should also include monitoring of the content of microplastics in the stomachs of benthic invertebrates and incorporating these findings into marine environmental management approaches. 
Acknowledgements Samples analysed in the present work were collected during the RV Kartesh cruises to the Pechora Sea in 2017 and 2018 and the authors are grateful to LMSU MRC for organising the cruises and to the RV Kartesh Captain and crew for their excellent work. The help of taxonomic experts in verifying identifications of animal fragments from the stomach contents is gratefully acknowledged: Anna Tikhonova, IO RAS (foraminifers); Uliana Simakova, IO RAS (macrophytes); Natalia Budaeva, University of Bergen (polychaetes); Maria Mardashova, LMSU MRC (molluscs, polychaetes); Glafira Kolbasova, LMSU MRC (polychaetes). The authors are also grateful to Dr. Andrey Gebruk, Nadia Jogee and anonymous reviewers for helpful feedback. This study was partly supported by RFBR Grant \#18-05-60053

\section{Compliance with ethical standards}

Conflict of interest The authors declare that they have no conflict of interest.

Open Access This article is licensed under a Creative Commons Attribution 4.0 International License, which permits use, sharing, adaptation, distribution and reproduction in any medium or format, as long as you give appropriate credit to the original author(s) and the source, provide a link to the Creative Commons licence, and indicate if changes were made. The images or other third party material in this article are included in the article's Creative Commons licence, unless indicated otherwise in a credit line to the material. If material is not included in the article's Creative Commons licence and your intended use is not permitted by statutory regulation or exceeds the permitted use, you will need to obtain permission directly from the copyright holder. To view a copy of this licence, visit http://creativecommons.org/licenses/by/4.0/.

\section{References}

Alvsvåg J, Agnalt AL, Jørstad KE (2009) Evidence for a permanent establishment of the snow crab (Chionoecetes opilio) in the Barents Sea. Biol Invasions 11(3):587-595

Arsenault DJ, Himmelman JH (1996) Size-related changes in vulnerability to predators and spatial refuge use by juvenile Iceland scallops Chlamys islandica. Mar Ecol Prog Ser 140:115-122

Avio CG, Gorbi S, Regoli F (2017) Plastics and microplastics in the oceans: from emerging pollutants to emerged threat. Mar Environ Res 128:2-11

Bakanev SV, Pavlov VA (2019) Materials establishing the total allowable catch of the snow crab-opilio in the Russian EEZ in the Barents Sea in 2020. In: Preliminary materials of the total allowable catch in the area of extraction (catch) of aquatic biological resources in the internal waters, territorial seas, the continental shelf and the EEZ of the Russian Federation and the Caspian Sea for 2020 (with environmental impact assessment). PINRO, Murmansk, pp 15-27 (in Russian)

Bakanev S, Dvoretsky A, Pavlov V, Pinchukov M, Zacharov D, Zolotarev P (2016) Commercial shellfish: status of commercial stocks. In: McBride MM, Hansen JR, Korneev O, Titov O (eds), Stiansen JE, Tchernova J, Filin A, Ovsyannikov A (co-eds) Joint Norwegian-Russian environmental status 2013. Report on the Barents Sea Ecosystem. Part II-complete report IMR/PINRO joint report series. IMR/PINRO, Moscow, pp 224-241

Bakanev SV, Pavlov VA, Goryanina SV (2017) Material justifying correction of the total allowable catch of the snow crab in the
EEZ of Russia in the Barents Sea in 2017. NM Knipovich Polar Institute of Fishery and Oceanography, Murmansk (in Russian)

Boudreau SA, Worm B (2012) Ecological role of large benthic decapods in marine ecosystems: a review. Mar Ecol Prog Ser 469:195-213

Brethes JC, Desrosiers G, Coulombe F (1982) Food of the snow crab (Chionoecetes opilio) from the southwestern part of the Gulf of St. Lawrence (Chaleur Bay area)

Brotskaya VA, Zenkevich LA (1939) Quantitative recording of bottom fauna of the Barents Sea. Proc Russ Res Inst Fish Oceanogr 4(3): 150 (in Russian)

Burukovsky RN (2009) Food and food relationships of shrimp. Izdatelstvo KGTU, Kaliningrad (in Russian)

Cartes JE (1998) Feeding strategies and partition of food resources in deep-water decapod crustaceans (400-2300 m). J Mar Biol Assoc UK 78(2):509-524

Chuchukalo VI, Nadtochy VA, Koblikov VN, Borilko OY (2011) Diet and some ecological features of the most widespread commercial crab species in the northwestern Sea of Japan in early spring. Russ J Mar Biol 37(7):558-569

Cunningham DT (1969) A study of the food and feeding relationships of the Alaskan king crab Paralithodes camtschatica. Master's thesis, San Diego State College

Denisenko SG, Denisenko NV, Lehtonen KK, Andersin AB, Laine AO (2003) Macrozoobenthos of the Pechora Sea (SE Barents Sea): community structure and spatial distribution in relation to environmental conditions. Mar Ecol Prog Ser 258:109-123

Denisenko NV, Denisenko SG, Lehtonen KK (2019a) Distribution of macrozoobenthos in an Arctic estuary (Pechora Bay, SE Barents Sea) during the spring flood period. Polar Biol. https://doi. org/10.1007/s00300-018-02452-6

Denisenko SG, Denisenko NV, Chaban EM, Gagaev SYu, Petryashov VV, Zhuravleva NE, Sukhotin AA (2019b) The current status of the macrozoobenthos around the Atlantic walrus haul-outs in the Pechora Sea (SE Barents Sea). Polar Biol. https://doi.org/10.1007/ s00300-018-02455-3

Divine LM, Bluhm BA, Mueter FJ, Iken K (2017) Diet analysis of Alaska arctic snow crabs (Chionoecetes opilio) using stomach contents and $\delta 13 \mathrm{C}$ and $\delta 15 \mathrm{~N}$ stable isotopes. Deep Sea Res Part II 135:124-136

d'Udekem d'Acoz C (1999) Inventaire et distribution des crustacés décapodes de l'Atlantique nord-oriental, de la Méditerranée et des eaux continentales adjacentes au nord de $25^{\circ} \mathrm{N}$. Collection des Patrimoines Naturels 40:1-383

Fagerli CW, Norderhaug KM, Christie HC (2013) Lack of sea urchin settlement may explain kelp forest recovery in overgrazed areas in Norway. Mar Ecol Prog Ser 488:119-132

Farrell P, Nelson K (2013) Trophic level transfer of microplastic: Mytilus edulis (L.) to Carcinus maenas (L.). Environ Pollut 177:1-3

Flaherty EA, Ben-David M (2010) Overlap and partitioning of the ecological and isotopic niches. Oikos 119(9):1409-1416

Gaevskaya NS (1948) Identification key to fauna and flora of the northern seas of the USSR. Sovetskaya Nauka, Moscow, p 372

Gebruk AA, Borisova PB, Glebova MA, Basin AB, Simakov MI, Shabalin NV, Mokievsky VO (2019) Macrozoobenthos of the shallow waters of Pechora Bay (Barents Sea). Nat Conserv Res 4(4):1-11. https://doi.org/10.24189/ncr.2019.058

Gebruk A, Mikhaylyukova P, Mardashova M, Semenova V, Henry L-A, Shabalin N, Naryanaswamy B, Mokievsky V (2020) Integrated study of benthic foraging resources for Atlantic walrus (Odobenus rosmarus rosmarus) in the Pechora Sea, south-eastern Barents Sea. Aquatic Conserv Mar Freshw Ecosyst. https://doi. org/10.1002/aqc.3418

Grebmeier JM (2012) Shifting patterns of life in the Pacific Arctic and sub-Arctic seas. Annu Rev Mar Sci 4:63-78 
Hammer Ø, Harper DAT (2006) Paleontological data analysis. Blackwell, Oxford

IUCN (2016) Odobenus rosmarus. The IUCN red list of threatened species 2016: e.T15106A45228501. https://doi.org/10.2305/IUCN. UK.2016-1.RLTS.T15106A45228501.en. Downloaded on 3 Dec 2020

Jackson AL, Inger R, Parnell AC, Bearhop S (2011) Comparing isotopic niche widths among and within communities: SIBER Stable Isotope Bayesian Ellipses in R. J Anim Ecol 80(3):595-602

Jewett SC, Gardner LA, Rusanowski PM (1989) Food and feeding habits of red king crab from north-western Norton Sound Alaska. In: Proceedings of the international symposium on King Tanner Crabs. University of Alaska Sea grant report 90-04, pp 219-232

Jørgensen LL, Spiridonov V (2013) Effect from the king-and snow crab on Barents Sea benthos. In: Results and conclusions from the Norwegian-Russian Workshop in Troms $\varnothing$, vol 2013

Kerbs A, Mueller P, Kaupp M, Ahmed I, Quick AS, Abt D, Wegener M, Niemeyer CM, Barner-Kowollik C, Fruk L (2017) Photoinduced click chemistry for DNA surface structuring by direct laser writing. Chem Eur J 23(21):4990-4994

Kolts JM, Lovvorn JR, North CA, Grebmeier JM, Cooper LW (2013) Effects of body size, gender, and prey availability on diets of snow crabs in the northern Bering Sea. Mar Ecol Prog Ser 483:209-220

Krebs CJ (1998) Ecological methodology, 2nd edn. Pearson, New York, p 620

Kucheruk NV, Kotov AV, Maximova OV, Pronina OA, Sapozhnikov FV, Malykh EA (2003) Benthos. In: Romankevich EA, Lisitsyn AP, Vinogradov ME (eds) The Pechora Sea: integrated research. More Pulishers, Moscow, pp 217-230 (in Russian)

Kulichkova VA (1955) Feeding of Kamchatka crabs during the spring-summer period on the shores of Kamchatka and Sakhalin. J Pac Sci Res Inst Mar Fish Oceanogr (TINRO) 43:21-42

Kun MS, Mikulich LV (1954) Diet composition of eastern crabs of commercial quality during the summer. J Pac Sci Res Inst Mar Fish Oceanogr (TINRO) 41:319-332

Kuznetsov VV (1964) Biology of the most common and abundant species of crustaceans of White and Barents Seas. Nauka, Moscow, p 241

Legeżyńska J, Kędra M, Walkusz W (2014) Identifying trophic relationships within the high Arctic benthic community: how much can fatty acids tell? Mar Biol 161(4):821-836

Linnebjerg JF, Hobson KA, Fort J, Nielsen TG, Møller P, Wieland K, Mosbech A (2016) Deciphering the structure of the West Greenland marine food web using stable isotopes $(\delta 13 \mathrm{C}, \delta 15 \mathrm{~N})$. Mar Biol 163:230. https://doi.org/10.1007/s00227-016-3001-0

Logvinovich DN (1945) Akvarial'nya nablyudeniya nad pitaniem Kamchatskogo kraba [Aquarium observations on the feeding of the Kamchatka crab]. In: Materialy po biologii promyslu o obrabotke Kamchatskogo kraba [Materials on biology, fishery and refinement of the Kamchatka crab]. Izv tikhookean nauchno Issled Inst ryb khoz Okeanogr 19:79-97 (in Russian, Japanese, and English)

Lorentzen G, Voldnes G, Whitaker RD, Kvalvik I, Vang B, Gjerp Solstad R et al (2018) Current status of the red king crab (Paralithodes camtchaticus) and snow crab (Chionoecetes opilio) industries in Norway. Rev Fish Sci Aquacult 26(1):42-54

Manushin IE, Pavlov VA, Pinchukov MA, Nosova TB (2016) Feeding of the snow crab Chionocetes opilio in the Barents and the Kara Seas. In: Sokolov KM, Strelkova NA, Manushin IE, Sennikov (eds) Snow crab Chionocetes opilio in the Barents and Kara seas. PINRO, Murmansk, pp 224-241 (in Russian)

Markowska M, Janecki T, Kidawa A (2008) Field observations of the spider crab, Hyas araneus (L., 1758): feeding behaviour in an Arctic fjord. Crustaceana 81:1211-1217
Michida Y, Chavanich S, Cabañas AC, Hagmann P, Hinata H, Isobe A, Martí E (2019) Guidelines for harmonizing ocean surface microplastic monitoring methods. Tokyo, Ministry of Enviroment Japan, p 71

Miller RJ (1981) Seasonal and depth distribution, size, and molt cycle of the spider crabs, Chionoecetes opilio, Hyas araneus, and Hyas coarctatus in a Newfoundland bay (no. C/639.805 C35/1003)

Mullowney D, Morris C, Dawe E, Zagorsky I, Goryanina S (2018) Dynamics of snow crab (Chionoecetes opilio) movement and migration along the Newfoundland and Labrador and Eastern Barents Sea continental shelves. Rev Fish Biol Fish 28(2):435-459

Murray F, Cowie PR (2011) Plastic contamination in the decapod crustacean Nephrops norvegicus (Linnaeus, 1758). Mar Pollut Bull 62(6): 1207-1217

Nadtochiy VA, Budnikova LL, Koblikov VN, Bezrukov RG (2004) The latest data on composition and quantitative distribution of macrobenthos on the Sea of Okhotsk shelf of Sakhalin Island. Izv Tikhookean Nauchno-Issled Inst Rybn Khoz Okeanogr 139:317339 (in Russian)

Newsome SD, Martinez del Rio C, Bearhop S, Phillips DL (2007) A niche for isotopic ecology. Front Ecol Environ 5(8):429-436

Nikiforov SL, Dunaev NN, Politova NV (2005) Modern environmental conditions of the Pechora Sea (climate, currents, waves, ice regime, tides, river runoff, and geological structure). Rep Polar Mar Res 501:7-38

Odintsov VS, Kiyashko SI (2018) Variations in the carbon and nitrogen isotope composition of the crabs Chionoecetes opilio (Fabricius, 1788) and Hyas coarctatus Leach, 1816 (Crustacea: Decapoda) from the Chukchi Sea. Russ J Mar Biol 44(1):68-74

Paar M, Lebreton B, Graeve M, Greenacre R, Asmus R, Asmus H (2019) Food sources of macrozoobenthos in an Arctic kelp belt: trophic relationships revealed by stable isotope and fatty acid analyses. Mar Ecol Progr Ser 615:31-49. https://doi.org/10.3354/ meps 12923

Pianka ER (1974) Niche overlap and diffuse competition. Proc Natl Acad Sci 71(5):2141-2145

Post DM, Layman CA, Arrington DA, Takimoto G, Quattrochi J, Montana CG (2007) Getting to the fat of the matter: models, methods and assumptions for dealing with lipids in stable isotope analyses. Oecologia 152:179-189

Pott A (2014) A new method for the detection of microplastics in the North Sea brown shrimp (Crangon crangon) by Fourier transform infrared spectroscopy (FTIR). Doctoral dissertation, RWTH Aachen University

Pushkina NS (2017) Comparative charcharacteristics of diet composition of the red king crab and four species of decapod crustaceans in the coastal zone of the Barents Sea. MS thesis, Kaliningrad State Technical University, Kaliningrad (in Russian)

R Core Team (2018) R: A language and environment for statistical computing. R Foundation for Statistical Computing, Vienna

RStudio Team (2016) RStudio: integrated development for R. RStudio, Inc., Boston

Semenova V, Boltunov A, Nikiforov V (2019) Key habitats and movement patterns of Pechora Sea walruses studied using satellite telemetry. Polar Biol 42:1763-1774

Sokolov KM, Strelkova NA, Manushin IE, Sennikov AV (eds) (2016) Snow crab Chionoecetes opilio in the Barents and Kara Seas. PINRO, Murmansk (in Russian)

Spiridonov V, Solovyev B, Chuprina E, Pantyulin A, Sazonov A, Nedospasov A, Glazov D (2017) Importance of oceanographical background for a conservation priority areas network planned using MARXAN decision support tool in the Russian Arctic seas. Aquat Conserv Mar Freshw Ecosyst 27:52-64

Spiridonov VA, Zalota AK, Pereladov M, Deart YV, Tiunov A, Britayev TA (2020) Fjordic lagoons of the Barents Sea as the model objects for studying dynamics of coastal communities 
with non-indigenous red king crab (Paralithodes camtschaticus, Decapoda, Lithodidae). Zoologicheskiy Zhurnal 99(7):801-818 (in Russian)

Squires HJ (1990) Decapod Crustacea of the Atlantic coast of Canada. Can Bull Fish Aquat Sci 221:532

Squires HJ, Dawe EG (2003) Stomach contents of snow crab (Chionoecetes opilio, Decapoda, Brachyura) from the Northeast Newfoundland Shelf. J Northw Atl Fish Sci 32:27-38

Sukhotin AA, Krasnov YV, Galaktionov KV (2008) Subtidal populations of the blue mussel Mytilus edulis as key determinants of waterfowl flocks in the southeastern Barents Sea. Polar Biol 31(11):1357-1363

Sukhotin A, Denisenko S, Galaktionov K (2019) Pechora Sea ecosystems: current state and future challenges. Polar Biol 42(9):1631-1645

Tarverdieva MI (1981) Feeding of snow crabs Chionoecetes opilio and Chionoecetes bairdi in the Bering Sea. Zool Zhurnal 76(3):287-293

Wieczorek SK, Hooper RG (1995) Relationship between diet and food availability in the snow crab Chionoecetes opilio (O.fabricius) in Bonne Bay, Newfoundland. J Crustac Biol 15(2):236-247

Zakharov DV, Manushin IE, Strelkova NA, Pavlov VA, Nosova TB (2018) Diet of the snow crab in the Barents Sea and macrozoobenthic communities in the area of its distribution. Trudy VNIRO 172:70-90 (in Russian)

Zalota A.K. 2017. Alien species of decapod crustaceans (Crustacea Decapoda) in the seas of Russia and adjacent waters. PhD dissertation, Moscow Shirshov Institute of Oceanology (in Russian)

Zalota AK, Spiridonov VA, Vedenin AA (2018) Development of snow crab Chionoecetes opilio (Crustacea: Decapoda: Oregonidae) invasion in the Kara Sea. Polar Biol 41(10):1983-1994

Zimina OL, Lyubin PA, Jørgensen LL, Zakharov DV, Lyubina OS (2015) Decapod crustaceans of the Barents Sea and adjacent waters: species composition and peculiarities of distribution. Arthropoda Selecta 24:417-428

Zmudczyńska-Skarbek K, Balazy P, Kuklinski P (2015) An assessment of seabird influence on Arctic coastal benthic communities. J Mar Syst 144:48-56

Publisher's Note Springer Nature remains neutral with regard to jurisdictional claims in published maps and institutional affiliations. 